\title{
CHALLENGE OF LEARNING ENGLISH FROM REVOLUTION AS 21st CENTURY LEARNING FOR COMMUNITIES 5.0
}

\author{
Dina Purnama Sari \\ Fakultas Komunikasi dan Bahasa, Universitas Bina Sarana Informatika Jakarta \\ dina.dms@bsi.ac.id
}

\begin{abstract}
Society 5.0 is a human-centered and technology-based society developed by Japan as the development of 4.0 industrial revolution. With the 5.0 community, it has an influence on $21 \mathrm{st}$ century learning, especially English. Therefore, research is limited to learn English which can be learned through various media in Indonesia, one of them online media. Regarding the background of the problem, the purpose of his research was to develop English language learning and community 5.0 in 21 st century learning in Indonesia with the limitation of the problem being English conversation learning in office administration for students in university. The research method was qualitative descriptive based on the results of observation, analysis, and literature review with the object of research being online media as learning, such as www.youtube.com. Meanwhile, the results of his researched are the variety of information and media in the community and the rapid development of technology will foster interest in learning English for the community. Thus, it could be concluded that there are many challenges to introduce, grew and developed English as a 21st century learning for 5.0 dynamic people in the digital era
\end{abstract}

Keywords: challenge, english languange, 21th century learning, online media. society 5.0

\section{INTRODUCTION}

The Industrial Revolution began with the Industrial Revolution 1.0. In the initial revolution, technology and civilization were still minimal by utilizing hunting and getting what was found, namely food gatherings. Then, the Industrial Revolution 2.0 developed. In the 2.0 industrial revolution, the product process became the food production that was originally collected. At this stage, the industrial revolution occurred at the agrarian stage. The next stage was the 3.0 industrial revolution occurred at the agrarian stage. The next stage was the 3.0 industrial revolution which was introduced in the UK, which initially used human power to become mechanical power. The next revolution is the industrial revolution was the revolution 4.0 which was dominated by advances in technology, information, data, internet, and artificial 
intelligence. The next stage that is being developed in Japan is the 5.0 Industrial Revolution. In the era of Industrial Revolution, a concept of human-based and technology-based society was formed. That is, the transformation of artificial intelligence will help humans to live more meaningful live. For example, in Japan, to cope with increasing costs and treatment of elderly patients, it can use data medical record to help speed up the handling of health (karinov, 2019).

In connection with the development of the industrial revolution, it has an impact on various fields, one of which is English. In the era of revolution 5.0, there were challenges in the field of English language educators to develop 21st century learning. The challenge was marked by various electronic learning media. Regarding the background of the problem, the purpose of his research was to develop English language learning and community 5.0 in 21 st century learning in Indonesia with the limitation of the problem being English conversation learning in office administration for students in university.

With regard to the background of the problem, there are some results of previous research, two of which were discussed by M. Marcellino (2008) in TEFLIN Journal, Volume 19, Number 1, February, 57-69; and Ranbir Singh Malik (2018) in the Journal of Sustainable Development Education and Research, JSDER Vol. 2, No.1, 9-20. Both of these preceding studies are one of the previous research bases developed by the researcher.

On the results of M. Marcellino's research, it was found that the success of teaching English in students in Indonesia was related to the background of customs, values, beliefs, and the political point of view of the government. In addition, other aspects are curriculum, teacher performance and the response of the students.

Results of discussion by Ranbir Singh Malik (2018) in the Journal of Sustainable Development Education and Research, JSDER Vol. 2, No.1, 9-20, discuss various educational reforms carried out in several education systems that are successful. In addition, there is a challenge for developing countries such as Indonesia or an area such as ASEAN to learn from such system experience and realize that ideas that work in a socio-economic environment can be effectively carried out in their settings. Thus, education needs to be prepared with a good system in order to produce human resources that are able to compete in the information and technology era and the phenomenon of dynamic environmental change.

Meanwhile, related to 21st Century learning, conceptually and applicative (1990), a meeting was held in Bangkok that talked about learning innovations in the 21 st century, "The UNESCO Principal Regional Office for Asia and the Pacific (PROAP) and the Asian Centre of Educational Innovation for Development (ACEID) convened in Bangkok in August 1990 a 
regional symposium to deliberate in the Asia-Pacific context on the issues of change in education for the twenty-first century."

The presentation about Perspectives of Change and Prospects. They are indicative of the assumptions on which the role of education for the future is surmised. The point to emphasis is that the surmising is not about what the future will be, but about the consequences and imperatives for the development of education which flow from the issues as they are forming.

Learning English, especially understanding conversations can be done in various ways, one of which is online media literacy (John Seely Brown, 2005). The following below is Figure 1: Evolving Forms of Literacy-the USC Multimedia Literacy Program concluded by John Seely Brown:

Figure 1: Evolving Forms of Literacy-the USC Multimedia Literacy Program

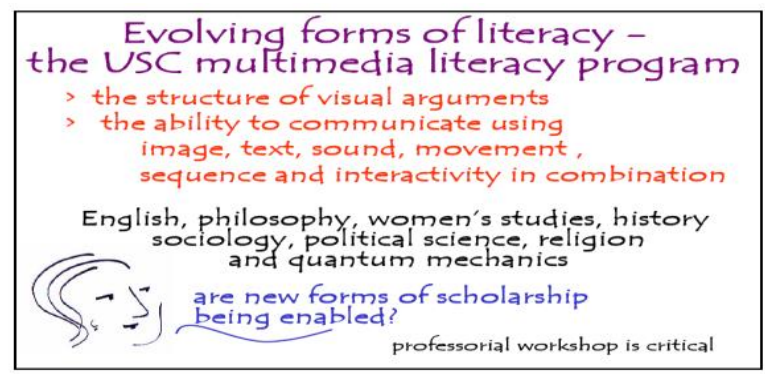

In Figure 1 Evolving Forms of Literacy-the USC Multimedia Literacy Program, to experiment with how to provide both students and faculty the chance to develop these new literacy skills. The purpose of this program is not to teach students about the tools of multimedia, but rather to focus on new expressive practices enabled by these tool. Example, how do you make a compelling visual argument?

In addition, in the learning curriculum there are new ideas that are important to produce workshops, workshops, discussions, or other training that reflect a positive provocative view of using multimedia as a learning tool Multimedia is used as a learning tool both indoors and outdoors so that it is effective and efficient. For example, as a hearing aid or visualization media in the video screen display. 
In general, learning, according to UNESCO (Jacques Delors, 2013), there are four pillars of education, namely, learning to know, learning to do, learning to live together, and learning to be. Four pillars of education, specialisation whereby learning to know happens at school, learning to do happens in the workplace, learning to be happens in the private sphere, and learning to live together happens in the public sphere.

Thus, based on the background of the problem, the purpose of the research, the preceding research, and the concepts related to the research topic, the problem can be formulated is how the challenge of learning English from the revolution as learning 21st century for society 5.0?

\section{METHOD}

The method used in this study is descriptive qualitative with data collection obtained based on the results of literature and analysis. Literature studies are carried out through references that are relevant to research, such as scientific journal articles and books. conducted by analyzing the findings of the results obtained in the field through initial data processing on the web wwwyoutube.com and literature studies based on theories that support in it.The object of the research is online media, which is some English learning channels found on www.youtube.com. In addition, the topic of discussion relates to the phenomenon of $21^{\text {st }}$ century learning in the era of revolution 5.0.

\section{FINDINGS AND DISCUSSION}

Based on the findings of the data obtained through observation, literature study, and analysis, two data related to the topic of the problem were obtained. Problems are limited to learning English for students in business administration study programs, especially business conversations, with dialects and work culture in Australia compiled by Adult Multicultural Education Services (A.M.E.S) as the largest Language Teaching Institute in Australia. Data collected is one of the choices from various dialects and work cultures that speak English as the main language used in the country. The data used uses internet media through www.youtube.com and is limited to only two data with their respective discussions. After learning to communicate via the internet, students are expected to understand and listen and then apply to the world of work as one of the skills in foreign languages so that they can compete in the 21 st century in the era of industrial revolution 5.0. Related with these, the following below is Picture 2 Bahasa Inggris untuk Bisnis 01 - Bagaimana Memperkenalkan Staf Perusahaan, (Nita Tiara, 2016). 
Figure 2, Bahasa Inggris untuk Bisnis 01 - Bagaimana Memperkenalkan Staf Perusahaan

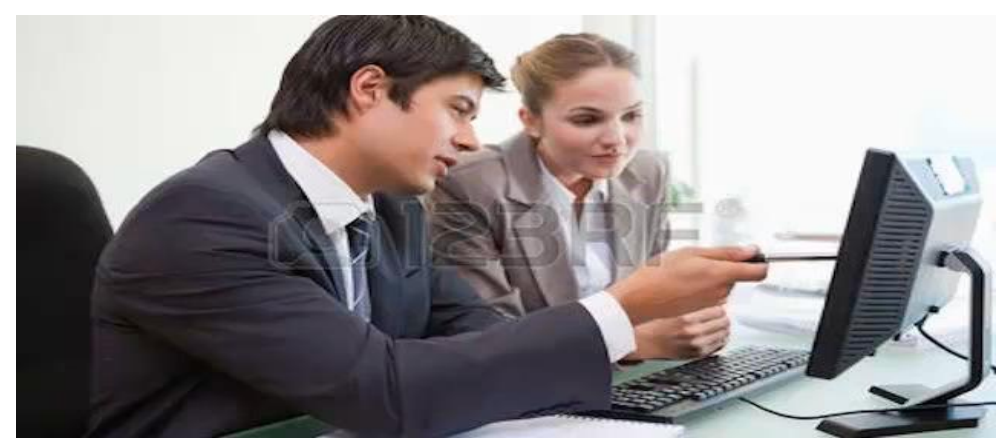

Based on Figure 2, Bahasa Inggris untuk Bisnis 01 - Bagaimana Memperkenalkan Staf Perusahaan, (Nita Tiara, 2016) retrieved fromhttps://www.youtube.com/watch?v=xz3qX16nro4 , provided material on procedures for dealing with work with people who work in English, especially in Australia. Before the conversation is held, a tutorial and repetition of the pronunciation are given. In addition, Indonesian translations and pronunciation training were repeatedly given. Not only sentence structure and vocabulary conversations, but also told effective communication tips and polite communication with colleagues in Australian companies. Meanwhile, the lesson consists of 1) self-introduction briefly, such as name, position, duty or responsibility, company briefly; and introducing one partner to another in the office.

The next data discussion is about introducing team / company staff part 2 (Niara, 2016). The discussion can be listened to via https://www.youtube.com/watch?v=8qBq7CJc_z0

Figure 3 Bahasa Inggris untuk Bisnis 02 - Memperkenalkan Tim/Staf Perusahaan

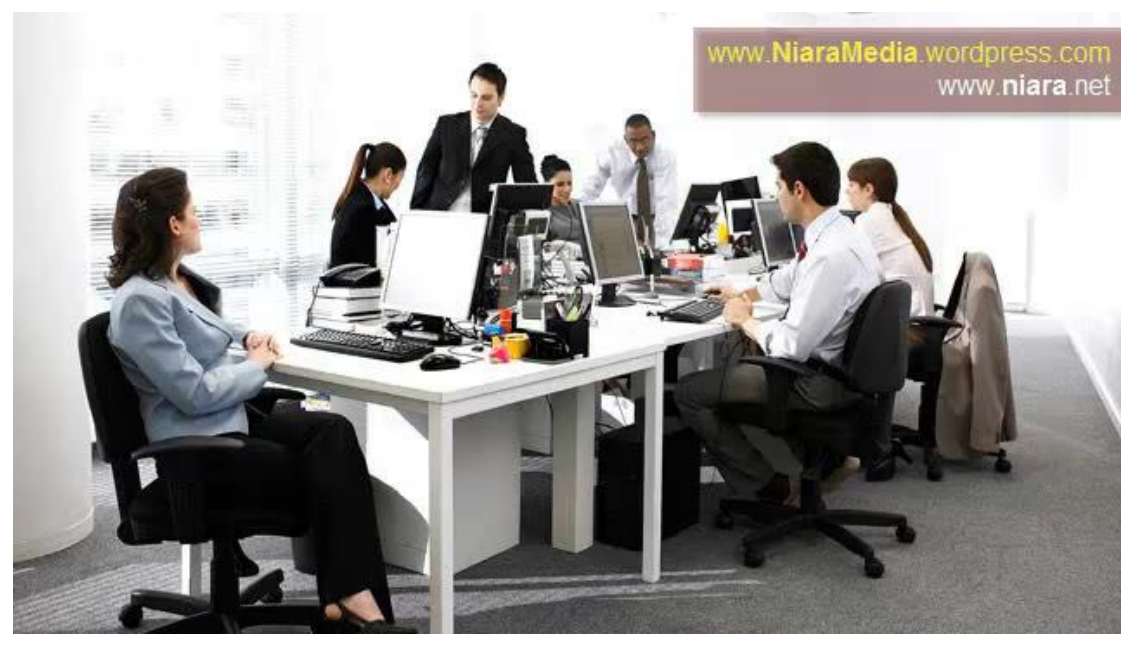


In the Business 02 discussion, it was a continuation of Bisnis 01. The discussion was about some new vocabulary in the form of abbreviations, for example CEO (Chief Executive Officer), 2Ic (Second in Charge), PA (Personal Asistant), and PR (Public Relations). In addition, specific terms of Australian humor and ethics joke with fellow employees or between subordinates and superiors or vice versa. Expressions and vocabulary open and respond to the opening of conversations with the team or staff, for example asking for help, discussing the weather, events that are busy being discussed, sports, and fine dining.

In Business Discussion 02, the procedure for learning, repetition of previous materialBusiness 02, and the stages of material to be given. In addition, the text was translated into Indonesian and its oral translation.

So, based on the findings of the two data, it can be analyzed that both are online tutorials provided by experts in the fields of English and Indonesian. Some learning stages have similarities, namely explanations of tutorials, recitation, important vocabulary, and accompanied by Indonesian translations.

Another analysis based on the findings of the data is that learners are given additional knowledge about the ethics of working in Australia both with colleagues, parties outside the company, and leaders. Thus, learners have soft skills and skills. This is consistent with the four pillars of education and challenges for the 5.0 dynamic community in the digital era as $21 \mathrm{st}$ century learning.

Meanwhile, community 5.0 is meant by business administration students in universities. By using online media, students are able to improve and develop their communication skills. That is, knowing English, using it both for themselves and the surrounding environment, and applying it to the existence and personal competence so that it becomes a qualified human resource.

\section{CONCLUSIONS}

Related to the previous study which related to the issue, it can be many ways to use English for community 5.0, one of them were from online community, such as www.youtube.com. And, based on the background, topic, and problems, it can be concluded that the use of English as an international language has challenges for the community 5.0 that are dynamic in the digital era as 21st century learning. Society 5.0 which is intended for this study students in universities, business administration study programs. In the era of revolution 5.0, the role of humans is quite important in it and competency is needed to use technology, one of which is online learning media, www.youtube.com. Online learning can be done not only on campus, but also at home or 
other places. With the learning of the media, it is easier for the 5.0 community to recognize, improve, and develop their language skills. In addition, four pillars of education can be applied properly. The purpose of this study is to improve the competence of writers in writing scientific essays, especially related to the field of education and research as well as the development of research in the field of English about the importance of the relation of the Industrial Revolution 5.0 with the use of technology along with the role and human resources in it. Related with those, recommendation for the next researchers are they can use more technology in different ways and use it for good education.

\section{Acknowledgments (if any)}

I would like to thanks all the academics of the University of Bina Sarana Informatika Jakarta and my family for giving all their support and assistance.

\section{REFERENCES}

Brown, John Seely. (2005). New Learning Environments for the 21st Century*retrieved from http://www.johnseelybrown.com/newlearning.pdf

Delors, Jacques. (2013). The treasure within: Learning to know, learning to do, learning to live together and learning to be. What is the value of that treasure 15 years after its publication? Int Rev Educ 59:319-330. retrieved from http://www.ooscimena.org/uploads/1/wysiwyg/Delors_article_review_of_education_2013.pdf

Karinov. (2019). Revolusi Industri Ala Jepang: Hjuman-Centered Society. Retrieved From https://Karinov.Co.Id/Revolusi-Industri-5-Jepang/

Malik, Ranbir Singh. (2018). Educational Challenges In 21st Century And Sustainable Development. Journal of Sustainable Development Education and Research. JSDER Vol. 2, No.1. 9-20. retrieved from File:///C:/Users/User.User-PC.000/Downloads/12266-256201-SM.Pdf

Marcellino, M. (2008). English Language Teaching In Indonesia: A Continuous Challenge In Education And Cultural Diversity. TEFLIN Journal, Volume 19, Number 1, February. 57 69. retrieved from http://journal.teflin.org/index.php/journal/article/viewFile/99/93

Niara, Kita. (2016). Bahasa Inggris untuk Bisnis 01 - Bagaimana Memperkenalkan Staf Perusahaan. Retrieved from https://www.youtube.com/watch?v=xz3qX16nro4 
Niara, Kita. (2016). Bahasa Inggris untuk Bisnis 02 - Memperkenalkan Tim/Staf Perusahaan Bag. 2. Retrieved from https://www.youtube.com/watch?v=8qBq7CJc_z0

Singh, Raja Roy. (1991). Education for The Twenty First Century: Asia-Pasific Perspective. Bangkok: UNESCO. retrieved from http://www.unesco.org/education/pdf/15_15.pdf 